\title{
DESAPROPRIAÇÃO - ARBITRAMENTO DA INDENIZAÇÃO EM QUANTIA SUPERIOR AO MÁXIMO LEGAL - HO- NORARIOS DE ADVOGADO
}

- Não se justifica que o poder público se locuplete com um valor econômico, reduzindo o patrimônio do expropriado mediante exígua indenização, sob o pretexto de qưe o critério estabelecido no parágrafo único do art. 27 é intransponível. A regra, portanto, do parágrafo único do art. 27 não pode ser imposta como critério imutável, rígido e absoluto. E' um critério de adoção recomendável em alguns casos, em outros não, cabendo ao Juiz dizer a êsse respeito a última palavra.

- A natureza do processo de desapropriação náo comporta a condenação em honorários de advogados, devidos exclusivamente nos casos previstos pelos arts. 63 e 64 do Código de Processo Civil.

- Interpretação do art. 27, parág. único, do Decreto-leí n. 3.365 , de 21-6-41.

\section{TRIBUNAL DE APELAÇÃO DO DISTRITO FEDERAL}

Irmandade de São José versus Prefeitura do Distrito Federal

Apelação n. 3.970 - Relator : Sr. Desembargador

RIBEIRO DA COSTA

\section{ACóRDÃo}

Vistos e relatados êstes autos de Apelação Cível n. 3.970 , entre partes, como primeira apelante a Irmandade de São José, segunda apelante a Prefeitura do Distrito Federal, e apeladas as mesmas:

Acordam os Juízes da Quarta Câmara do Tribunal de Apelação do Distrito Federal, pelos votos do Relator e Revisor, dar provimento à primeira apelação, prejudicada a segunda, a fim de reformar, em parte, a sentença apelada, para fixar a indenização devida nas somas de Cr\$ $855.360,00$ e Cr\$ $633.950,60$, respectivamente, pelos imóveis números 14 e 16 da Rua D. Manuel.

Custas ex-lege.

E' dêste parte integrante o relatório de fls. 87 .

A sentença apelada houve por bem considerar que, "em face dos dispositivos do Decreto n. ${ }^{\circ}$ 3.365, tratando-se de imóveis sujeitos ao impôsto predial, é de ser obedecida uma limitação no quantum da indenização, donde não ser aconselhável, digo acolhível, a pretensão de uma indenização correspondente 20 valor venal dos imóveis". Fiel a êsse critério, fixou a sentença a indenização devida, em relação aos dois prédios n. ${ }^{\circ} 14$ e 16 da Rua D. Manuel, no limite máximo permitido pelo parágrafo único do art. 27 , daquele decreto, ou seja em Cr\$ $654.720,00$ e Cr $\$ 370.744,00$, respectivamente.

A oferta da expropriante atingira as importâncias de $\operatorname{Cr} \$ 586.000,00$ e $270.000,00$.

O fundamento de que o ato de expropriação representa a preponderância do interêsse público sôbre o privado, quando os dois se acham em colisão, segundo a lição do ingigne CLóvis, invocado nas razões do ilustre patrono da segunda apelante, não pode alicerçar senão a relevância daquele interêsse no sentido da legalidade que se presume e de que se reveste o ato. 
Mas não justifica - e nem foi com êsse alcance que a lição veio expedida - que o poder público expropriante se locuplete com um valor econômico, reduzindo o patrimônio do expropriado, mediante exígua indenização, sob o pretexto, sem o menor formato de direito, nem de justiça, de que o critério estabelecido no parágrafo único do art. 27 é intransponível.

Essa intransponibilidade, se admitida e inviolavel, reduziria o Juiz, chamado a dirimir a controvérsia, ao automatismo meramente homologatório, cuja passividade não se harmoniza com a função, que a lei the outorga, de dirimir, decidir, julgar, isto é, de fato e de direito, a lide, pondo têrmo ao dissídio, terçando as ferramentas da razão, da lógica, do justo, da eqüidade, do decente, da moral, do humano razoável ou em suma do direito e da lei.

Ora, por isso mesmo, determina o Decreto-lei n.o 3.365 , de 21 de junho de 1941 pelo seu art. 12 , que "sòmente os Juízes que tiverem garantia de vitaliciedade, inamovibilidade e irredutibilidade de vencimentos poderão conhecer dos processos de desapropriação", isto é, só os magistrados investidos de garantias excepcionais são chamados a decidir na espécie, atentos os altos interêsses não só do poder público, como, assim, dos particulares.

Em seu art. 14, manda a lei que o Juiz, ao despachar a inicial, designará um perito de sua livre escolha, sempre que possível técnico, para proceder à avaliação dos bens.

Além disso, dispõe o art. 27 que 0 Juiz indicará na sentença os fatos que motivaram o seu convencimento e deverá atender, especialmente, à estimação dos bens para efeitos fiscais; ao preço da aquisição e interêsse que dêles aufere o proprietário; a sua situação, estado de conservação e segurança; ao valor venal dos da mesma espécie, nos últimos cinco anos e valorização ou depreciação da área remanescente, pertencente ao réu.

E ainda estabelece, pelo art. $28,810^{\circ}$, que o Juiz recorrerá ex-officio quando condenar a Fazenda Pública em quantia superior ao dôbro da oferecida.

Tudo isso que a lei dispõe está a indicar a magnitude da função dispensada ao Juiz no processo judicial relativo à ação de desapropriação; as regras, tendentes à exata fixação da indenização devida, mediante a intervenção de perito, sempre que possível técnico, as circunstâncias peculiares aos interêsses em jôgo, como sejam o preço dos bens, a sua renda, sua situação, estado de conservação e segurança, valor venal em relação aos da mesma espécie nos Lltimos cinco anos etc.; compulsoriedade de recurso pelo próprio Juiz, quando na sentença condenar a Fazenda Públiea em quantia superior ao dóbro da oferecida.

Incontestàvelmente, quis o legislador que o Juiz, sopesando tôdas essas circunstâncias, levasse em conta o valor, em conjunto, da propriedade imóvel, sujeita a expropriação, para the fixar a indenização aproximada, em função de sua utilidade econômica.

A regra, portanto, do parágrafo único do art. 27 não pode ser imposta como critério imutável, rijo e absoluto.

E' um critério de adoção recomendável em alguns casos, em outros não, cabendo ao Juiz dizer a êsse respeito a última palavra.

No momento atual êsse critério não pode nem deve ser atendido, senão excepcionalmente, porquanto o valor locativo, na vigência das sucessivas leis sôbre locação de imóveis, é estável, muito embora o valor da propriedade imobiliária 'esça, dia a dia, à proporção que se acentua o fenômeno da inflação de - ssa moeda.

Não consulta ao interêsse da coletividade, nem à propalada socialização do direito, expressão de que se usa e abusa sem a necessária adequação, armar o poder expropriante de faculdade tal que a sua vontade exclusiva pode, de um 
golpe, reduzir o valor locativo dos imóveis, e, de outro, decretar-lhe a expropriação, para mais adiante efetuar a revenda, por preço alto, o que redundaria, como vai sucedendo, no aumento excessivo do preço dos aluguéis, preços asfixiantes, tolerados em detrimento da economia popular.

O problema é dos mais graves e sôbre êle há que ponderar com a devida previdência, antes que se torne impossivel neutralizar as suas desastrosas consequêencias, que já se fazem sentir com alarmante inquietação dos rnenos farorecidos da sorte.

Os fatôres econômicos não são um brinquedo de polichinelo.

Para êles o legislador atenta, numa visão sábia e cautelosa, no interêsse do bem comum.

Assim, a indenização deve representar o justo ressarcimento pelo valor da propriedade imóvel, objeto da desapropriação, na maneira por que é estatuído na Carta Constitucional (art. 122, n. ${ }^{\circ} 14$ ).

$\mathrm{Na}$ acepção jurídica, o têrmo indenização corresponde ao refazimento ou composição de um dano sofrido, à equivalência de um valor econômico lesado, abolido, extinto ou destruído.

Por essa razão, tocio critério, impôsto pelo legislador ordinário, que se afaste, nesse particular, do escopo visado pelo preceito constitucional, porque ofenda a êsse preceito, deve ser pôsto à margem, negando-se-lhe a aplicação compulsória.

Considerando dessa ordem, sob vestes melhores, já as explanaram sucessivos julgados não só cêste Tribunal cơmo, ainda, do egrégio Supremo Tribunal Federal (agravo de Instrumento n. ${ }^{\circ} 10.914$, relator o doutor Ministro Orozimbo NONATO, em 13 de abril de 1943; Recurso Extraordinário n. ${ }^{\circ} 6.185$, de 4 de outubro de 1943, relator o eminente Ministro ANíbal Freire).

Dêste Tribunal, ocorre citar, dentre outros, o acórdão proferido na Apelação Cível n. ${ }^{\circ} 2.276$ (apenso $219, D . J$. de 10 de setembro de 1943 , pág. 6.597, Jurisp. Trib. Apel. vol. XVII, 1944, págs. 55, 116, 134, 164, 165, 166, 167; recentíssimo acórdão da Quinta Câmara, relatado pelo ilustre Desembargador CÂNDIDo LôBo, de 11 de abril de 1944, in $D$. J., apenso 166, pág. 3.277).

Pendente de embargo, o acórdão da Terceira Câmara, da lavra do nobre e ilustre Desembargador FialHo na Apelação Cível n. ${ }^{\circ} 2.276$, de 23 de julho de 1943.

Há a considerar, pois, como o proclama aliás o provecto $\mathrm{Dr}$. Juiz a quo, não sòmente a situação dos imóveis em questão, mas, além disso, a área por êles compreendida, o valor da edificação, a renda respectiva, o valor venal dos imóveis adjacentes.

Atestam as fotografias juntas ao processo que se trata de prédios de grande vulto.

O local, muito próximo à famosa esplanada do Castelo, é dos de maior valorização.

Os laudos de fls 24 e 27, de que é signatário o Engenheiro F. V. de Mirando Carvalho, justificam o arbitramento adotado para ambos os imóveis, tendo em conta os respectivos valores atuais e reais, devendo, pois, nessa base, que é justa, ser fixada a indenização a que fica obrigada a expropriante.

Por outro lado, dada a natureza do processo de desapropriação, não cabe a condenação da segunda apelante nos honorários de advogado, devidos exclusivamente nos casos previstos pelos arts. 63 e 64 do Código do Processo Civil.

Nesse tocante bem decidiu a sentença recorrida.

Rio, 28 de julho de 1944. - Edmundo de Oliveira Figueiredo, Presidente e Revisor. - A. M. Ribeiro da Casta, Relator. 